\title{
PENEGAKAN HUKUM YANG BERKEADILAN DALAM PERSPEKTIF FILSAFAT HERMENEUTIKA HUKUM: SUATU ALTERNATIF SOLUSI TERHADAP PROBLEMATIKA PENEGAKAN HUKUM DI INDONESIA
}

\author{
Agus Budi Susilo \\ Pengadilan Tata Usaha Negara Yogyakarta \\ e-mail:bagoez007@gmail.com
}

\begin{abstract}
ABSTRAK
Esensi dalam penegakan hukum adalah keadilan. Keadilan itu sendiri mempunyai berbagai macam makna, tergantung dari perspektifnya. Di negara mana pun sering timbul berbagai masalah, terkait penegakan keadilan di ranah hukum. Konsep keadilan yang sudah mapan di suatu negara belum tentu baik apabila diterapkan untuk negara lain. Meskipun demikian, dimungkinkan adanya saling pengaruh mempengaruhi atau bersifat integrasi antara pemikiran satu dengan yang lainnya mengenai makna keadilan, terutama yang mempunyai sifat universal. Pada tataran filosofis, tentu masing-masing negara mempunyai akar pemikiran tersendiri, tergantung dari norma dasar negara dan kehidupan sosial-budaya bangsanya. Untuk mengurai lebih lanjut mengenai makna keadilan dari sudut pandang filsafat, sarana yang tepat digunakan adalah hermeneutik. Penelusuran keadilan dalam perspektif hermeneutik dalam rangka penegakan hukum seyogyanya dibingkai juga dengan perspektif ilmu hukum, agar diperoleh titik temu dan lebih mudah dalam pengimplementasiannya.
\end{abstract}

Kata Kunci: keadilan, hermeneutik, ilmu hukum dan penegakan hukum.

\begin{abstract}
The essence of the rule of law is justice. Justice has many meanings, depending on the perspective. Every country often arise various problems, related to the administration of justice in the realm of law. The concept of justice that have been established in a country is not necessarily better when applied to other countries. However, it is possible to mutual influenced or be integrated between each other thinking about the meaning of justice, particularly those having a universal nature. At the philosophical level, each country has own thoughts of the roots, depending on the basic norms and socio-cultural life of the nation. Thus, about the meaning of justice from the view of philosophy, the proper tools are used is hermeneutic. Search justice in the perspective of hermeneutics in the context of law enforcement should also be framed by the perspective of jurisprudence, in order to obtain the intersection and its implementation easier.
\end{abstract}

Keywords: justice, hermeneutics, legal studies and law enforcement.

\section{PENDAHULUAN}

Negara Indonesia saat ini sedang dilanda berbagai masalah hukum, ekonomi, sosial, politik, dan sebagainya. Bukan hanya ilmuwan berbagai perguruan tinggi saja yang gelisah menghadapi multiproblem ini, bahkan sebagian aparatur pemerintahan baik yang berada di lembaga eksekutif, legislatif, yudikatif, dan rakyat pun turut gelisah dengan keadaan tersebut.

Sering diadakan diskusi, penelitian, dan penelaahan mengenai masalah tersebut, dari sudut pandang keilmuan yang berbeda, tetapi tidak menghasilkan solusi apa pun. Setelah diselidiki secara seksama dalam perspektif global ternyata permasalahan itu tidak terjadi di Indonesia saja, bahkan di negara maju seperti Amerika Serikat pun menghadapi masalah multidimensi yang ditandai dengan adanya tsunami ekonomi yang menghancurkan pondasi sistem moneter di negara itu tahun 2008 hingga saat ini (termasuk juga beberapa negara di Eropa).

Fenomena ini, ada kesamaan dengan apa yang dinyatakan oleh Fritjof Capra yaitu di awal dua dasawarsa terakhir abad kedua puluh, akan ada krisis global yang serius, yaitu suatu krisis kompleks dan 
multidimensional yang segi-seginya menyentuh setiap aspek kehidupan. Krisis ini merupakan krisis dalam dimensi-dimensi intelektual, moral, dan spiritual; suatu krisis yang belum pernah terjadi sebelumnya dalam catatan sejarah umat manusia (Fritjof Capra, 1982:1).

Berbagai krisis multidimensi di berbagai negara, dari kacamata ilmu hukum, tentu ada suatu sistem yang salah, salah satunya masalah sistem hukum yang ada, yaitu tidak terimplementasikannya nilai-nilai keadilan yang di dalamnya terdapat unsur moralitas dan ini berlaku secara universal. Misalnya terjadinya krisis di Amerika Serikat, salah satunya terkait akibat dari tidak diterapkannya pelaksanaan nilai keadilan dan moralitas terhadap penyelesaian masalah di Timur Tengah dan beberapa negara Afrika (dana pemerintah habis hanya untuk berperang, bahkan konsep berperangnya pun jauh dari prinsip equity, humanity dan ethics). Begitu pun permasalahan hukum yang terjadi di Indonesia, sudah mencapai titik nadir. Hal ini ditandai dengan sudah tidak percayanya rakyat terhadap realisasi hukum positif di Indonesia, terutama dalam penegakan hukum positif itu sendiri.

Khusus untuk Indonesia, penegakan hukum positif dapat berwibawa dihadapan rakyat dan kalangan internasional apabila keadilan dapat berfungsi dan selalu hidup di dalam raga hukum. Tanpa menegakkan keadilan dalam hukum, akan menimbulkan penyimpangan dan penyalahgunaan siapa pun yang memegang kekuasaan atau kewenangan, yang nantinya berdampak buruk bagi tatanan sosial di masyarakat, sehingga muncul krisis sosial secara regional bahkan dapat berimplikasi secara internasional. Dalam peta pemikiran mengenai keadilan dan hukum, seyogyanya kita belajar dari para filusuf (mengambil yang baik dan meninggalkan yang buruk), dengan menelusuri sejarah perkembangannya yang dimulai dari zaman peradaban Yunani, dilanjutkan zaman Romawi, pada abad pertengahan aufklarung dan zaman modern yang dijuluki era informasi teknologi, hingga pada saat ini yang mulai muncul paham postmodern.

Postmodern disini, merupakan kritik filosofis atas gambaran dunia (world view), epistemologi dan ideologi-ideologi modern (I. Bambang Sugiharto, 1996:24). Dalam memaknai keadilan dan hukum atau hubungan keduanya, satu sama lain ada perbedaan pendekatan dan metodiknya serta karakteristiknya. Berangkat dari pemikiran-pemikiran para filusuf tersebut, akan diperoleh kesimpulan yang melandasi arti keadilan dan hukum itu sendiri, terlepas ada sisi positif dan negatifnya.
Hasil pemikiran mengenai keadilan dan hukum, dari masing-masing filusuf dalam penggunaannya bisa ada yang sesuai diterapkan di negara atau juga tidak sesuai di lain negara, karena itu tergantung dengan strata atau tatanan sosial, budaya, dan kelangsungan hidup suatu masyarakat yang mempunyai nilai kearifan regional atau lokal yang berbeda satu dengan lainnya. Oleh karenanya, ketika akan mengadopsi hasil pemikiran dunia barat tersebut harus benarbenar disaring apakah akan terjadi kontradiksi atau tidak dengan filosofi dasar negara maupun hukum asli bangsa kita.

Intisari dapat diambil dalam sejarah pemikiran dunia barat, pada dasarnya berkisar pada tataran individualisme, kolektivisme, liberalisme dan hanya sedikit yang mengagungkan humanisme maupun nilainilai religius. Teori-teori yang dimunculkan itu dari sudut pandang asas tentu berbeda dengan pemikiran yang berada di dunia timur, seperti Indonesia. Sehingga menjadi suatu hal yang menarik apabila dikaji lebih lanjut, mengenai filsafat yang tepat untuk Indonesia dalam memberi makna atau ruh mengenai konsep keadilan dan hukum.

Penerapan pemikiran barat ada dan digunakan mayoritas kaum yuris di Indonesia adalah yang tidak pas untuk diterapkan negara Indonesia sehingga menimbulkan chaos di bidang hukum, ini semua akibat ulah beberapa pemikir (ilmuwan hukum) dan pengguna hukum (praktisi hukum) di Indonesia. Chaos disini ditandai dengan ketidakstabilan serta keteracakan (randomness) proses hukum dalam berbagai dimensinya. Chaos yang penulis maksud disini adalah chaos yang bersifat negatif, karena chaos ada juga yang bersifat positif. Bahkan dimungkinkannya merubah negative chaos menjadi positive chaos (Sudjito, 2006:168 dan 172).

Ada beberapa yang beranggapan, ini semua merupakan produk gagal pendidikan hukum beberapa akademisi terdahulu yang mencetak beberapa pemikir sebagai generasi penerus (kader-kadernya) dan para penegak hukum (advokat, polisi, jaksa, dan hakim) yang dari hari ke hari tidak sadar telah berprinsip mengkerdilkan hukum, dengan dalih positivistiknya tentang hukum, sehingga hukum pun menjadi kehilangan eksistensinya (Satjipto Rahadjo, 2009: 32-33, dan 37).

Muncul aliran baru (non-doktrinal) yang selalu gelisah terhadap rusaknya hukum di Indonesia, yaitu menawarkan suatu pemahaman hukum secara holistik dan komprehensif keilmuan. Hukum tidak bisa kesepian karena menyendiri, hukum harus juga bersosialisasi dan bergandeng tangan dengan ilmu- 
ilmu lainnya. Akan tetapi paham ini, selalu mendapat tentangan dari paham konservatif yang menyatakan hukum itu harus tetap murni sebagaimana mestinya supaya tidak kehilangan jati dirinya (doktrinal).

Benturan antara kedua paham (doktrinal atau positivisme dengan non-doktrinal atau empirisme) itu tetap terjadi hingga saat ini, dengan konsepnya masing-masing terus berjalan tetapi belum ada titik temu. Perlu ada suatu konsep tertentu yang agar mudah dipahami dan diterima para kaum legisme, supaya menerima paham yang jauh lebih baik dan bisa memberikan solusi terhadap kekacauan hukum saat ini.

Konsep yang bisa diterima oleh kedua paham tersebut, tentu konsep yang memberikan makna yang gamblang mengenai keadilan yang cocok untuk penegakan hukum di Indonesia. Dalam khasanah filsafat, untuk menelusuri mengenai makna keadilan yang kompatibel bagi hukum Indonesia, alur pikir yang digunakan adalah filsafat hermeneutik.

Filsafat hermeneutik ini, merupakan aliran filsafat kontemporer yang berpola penafsiran. Pentingnya filsafat ini digunakan dalam membedah makna keadilan sebagai sebuah solusi dalam penegakan hukum di Indonesia dikarenakan hermeneutik konsekuen terikat pada dua hal kajian, yakni memastikan isi dan makna sebuah kata, kalimat, teks, dan sebagainya, dan menemukan instruksi-instruksi yang terdapat di dalam bentuk-bentuk simbolis (Josef Bleicher, 2007:5).

Uraian singkat di atas, menjadikan penulis prihatin dengan benturan dua konsep (doktrinal dan nondoktrinal) tersebut, bahkan ada pihak yang sengaja membentur-benturkan sehingga terjadi kegoncangan sangat dahsyat yang implikasinya berdampak negatif terhadap penegakan hukum di Indonesia (misalnya: kriminalisasi maupun politisasi terhadap pimpinan KPK (Komisi Pemberantasan Korupsi) oleh para politisi dan penegak hukum lainnya, sehingga terjadi benturan pandangan dalam memahami dua paham tadi). Ironi yang terjadi dan menjadi pihak dalam benturan tersebut, adalah stakeholder bidang hukum di Indonesia (selain politisi di bidang hukum dan para penegak hukum, juga melibatkan para ilmuwan hukum).

\section{RUMUSAN MASALAH}

Untuk menganalisa secara filosofis-yuridis permasalahan sebagai berikut: Dari perspektif filsafat hermeneutik, faktor-faktor apakah yang menyebabkan keadilan sulit untuk ditegakkan di Negara Indonesia, dan bagaimana filsafat hermeneutik memberi solusi yang terbaik untuk menjawab permasalahan tersebut terutama bagi para penegak hukum di Indonesia.

\section{METODE PENELITIAN}

Untuk menjawab permasalahan tersebut, penulis tidak melakukan secara deep research (penelitian yang mendalam), sehingga dalam mengeksplorasi dan mengeksploitasi bahan penulisan hanya berupa menggunakan pendekatan pemikiran-pemikiran para ahli filsafat dan hukum, khususnya ditinjau dari aspek hermeneutik. Pendekatan yang digunakan pun menggunakan deskriptif-analitis secara sederhana dengan menelusuri bahan-bahan tertulis yang ada (lite-rature).

\section{PEMBAHASAN \\ Pengertian Keadilan dalam Perspektif Filsafat Hermeneutik dan Filsafat Ilmu Hukum}

Arti secara terminologi dari filsafat adalah suka pada kebijaksanaan atau teman kebijaksanaan, yang asal katanya dari bahasa Arab filsafah yang berasal dari bahasa Yunani philosophia. Philos berarti suka atau cinta, dan sophia berarti kebijaksanaan. Sedangkan arti secara praktisnya filsafat berarti alamberfikir jadi berfilsafat ialah berfikir secara mendalam dan dengan sungguh-sungguh (H. Hasbullah Bakry, 1981:7).

Dalam filsafat, ada cabang filsafat yang membahas mendalam mengenai makna, yakni hermeneutika. Pengertian hermeneutika secara etimologis adalah menafsirkan, ini merupakan kata yang berasal dari bahasa Yunani yaitu hermeneuein. Jadi, kata bendanya adalah hermeneia yang secara harfiah artinya penafsiran atau interpretasi. Sedangkan dalam batasan umum, hermeneutika adalah suatu proses mengubah sesuatu atau situasi ketidaktahuan menjadi mengerti (E. Sumaryono, 1999:23-24).

Hermeneutika mempunyai dasar lingkaran berupa kesatuan titik-titik acu (roh) yang menyebabkan sesuatu menjadi bermakna. Disini, hermeneutika bertugas (meminjam istilah Ast) yang dirumuskan dalam tiga bentuk pemahaman, yaitu pemahaman materi yang diperbincangkan di dalam keadilan hukum, pemahaman bahasa keadilan hukum, dan pemahaman roh keadilan hukum, yaitu berupa pemahaman roh zaman dan pandangan semesta dari para pembuat dan pelaksana hukum yang saling berinteraksi serta saling menerangi satu sama lain (W. Poespoprodjo, 2004:21). Dengan demikian filsafat hermeneutik, merupakan filsafat yang menelusuri tentang suatu makna dengan menggunakan metode penafsiran apa yang ada di dalam suatu kata 
atau teks itu, yaitu menyingkap tabir di dalamnya. Misalnya penelusuran makna keadilan dalam konteks ke Indonesiaan, apabila menggunakan filsafat hermeneutik, tentu akan menyingkap baik dari segi linguistiknya maupun kontekstualitasnya.

Salah satu pemikiran filsafat hermeneutik yang sering menjadi rujukan dalam bidang penegakan hukum adalah pemikiran dari Francis Lieber. Lieber menafsirkan hermeneutik secara umum, yaitu menganggap cabang ilmu pengetahuan ini membahas prinsip-prinsip dan aturan interpretasi dan konstruksi. Menurutnya secara etimologis pengertian hermeneutik yang berarti menjalankan interpretasi ini berbeda dengan eksegesis yang berarti penjelasan. Jadi hermeneutika dibandingkan eksegesis ibarat teori dibandingkan dengan praktik, karena penafsiran pada umumnya meliputi segala cabang (ilmu pengetahuan) dimana kita terhubung secara cermat dengan makna kata-kata dan mengatur tindakan sesuai dengan semangat dan kandungannya yang sebenarnya (Gregory Leyh, 2008:127).

Prinsip-prinsip interpretasi dalam hermeneutika, menurut Lieber sebagai berikut: a. Suatu kalimat, atau bentuk kata-kata, hanya bisa memiliki satu makna yang benar; $b$. Tidak ada interpretasi yang sehat kecuali dengan adanya keyakinan yang baik dan akal sehat; c. Dengan demikian, kata-kata harus dipahami sebagaimana yang mungkin dimaksudkan oleh penutur; d. Apa yang bersifat khusus dan lebih rendah tidak bisa mengalahkan apa yang bersifat umum dan lebih tinggi; e. Perkecualian (terhadap huruf e) didasarkan pada apa yang lebih tinggi; f. Apa yang bersifat mungkin, sedang, dan lazim, lebih diutamakan daripada apa yang tidak mungkin, tidak sedang, dan tidak lazim; g. Kita mengikuti aturan-aturan khusus yang diberikan oleh otoritas yang tepat; $h$. Kita berupaya mendapatkan bantuan dari apa yang lebih dekat, sebelum mengarah pada apa yang kurang dekat; i. Interpretasi bukan tujuan melainkan merupakan sarana, dengan demikian kondisi-kondisi yang lebih tinggi dimungkinkan keberadaannya (Gregory Leyh, 2008:142).

Selain merinci prinsip-prinsip interpretasi sebagai unsur hermeneutik, Lieber pun memerinci prinsipprinsip konstruksi dalam hermeneutik sebagai berikut: a. Semua prinsip interpretasi, jika memang bisa diterapkan pada konstruksi adalah hal yang sah pula bagi yang tersebut kedua; b. Petunjuk utama bagi konstruksi adalah analogi, atau lebih tepatnya penalaran melalui paralelisme; c. Tujuan dan maksud suatu instrumen, hukum, dan seterusnya, bersifat esensial jika memang diketahui secara tersendiri, dalam upaya penafsirannya; d. Begitu juga hal itu bisa terjadi pada kausalitas hukum; e. Tidak ada teks mengenai pembebanan kewajiban yang menuntut halhal yang mustahil dilakukan; f. Hak-hak istimewa atau pengutamaan harus ditafsirkan sedemikian rupa sehingga tidak merugikan bagi mereka yang tidak memiliki hak istimewa atau yang tidak diutamakan itu; g. Semakin besar peran serta teks dalam suatu kesepakatan yang tertata dan resmi, maka semakin cermat pula seharusnya konstruksinya; $h$. Suatu teks yang menekankan pelaksanaan mengekspresikan segisegi yang bersifat minimum, jika pelaksanaan tersebut membebani si pelaksana, dan maksimum jika hal itu melibatkan pembebanan atau penderitaan di pihak lain; i. Konstruksi harus sesuai dengan substansi dan semangat umum teks; j. Efek-efek yang berasal dari konstruksi tertentu bisa menuntun kita untuk memutuskan konstruksi mana yang perlu kita ambil; k. Semakin tua sebuah hukum atau teks yang memuat peraturan mengenai tindakan kita, meskipun digariskan pada waktu yang telah silam, akan semakin luas pula cakupan konstruksinya dalam kasus-kasus tertentu; 1. Tidak ada hal yang bisa memberikan perlindungan substansial bagi kebebasan individu selain kebiasaan menjalankan konstruksi dan interpretasi secara seksama; m. Penting untuk kita pastikan apakah kata-kata yang digunakan memiliki karakter terbatas, mutlak, dan bermakna khusus, atau memiliki karakter umum, relatif atau ekspansif; $n$. Upayakan agar pihak yang lemah bisa mendapatkan manfaat dari ketentuan yang mengandung hal-hal yang meragukan, tanpa mengalahkan tujuan umum hukum. Upayakan agar belas kasih berlaku jika memang ada keraguan yang nyata; o. Diperlukan adanya pertimbangan atas keseluruhan teks atau wacana agar kita bisa melakukan konstruksi secara tepat dan benar; p. Di atas segalanya, upayakan untuk bersikap tepat dalam semua konstruksi. Konstruksi terwujud sebagai upaya membangun unsur-unsur dasar, dan bukan berupa pemaksaan suatu materi luar ke dalam teks (Gregory Leyh, 2008:142-143).

Dari kedua prinsip-prinsip (interpretasi dan konstruksi) yang dikemukakan Lieber ini, terlihat bahwa menerapkan hermeneutik dalam berhukum selain bagaimana kita berupaya menemukan dan menyajikan makna yang sebenarnya dari tandatanda apa pun yang digunakan menyampaikan ideide termasuk makna keadilan, juga menarik suatu kesimpulan mengenai pokok bahasan ada di balik ekspresi langsung teks, dari unsur-unsur tersebut yang diserap adalah semangatnya bukan pada huruf yang tertera pada teks, jadi dalam memahami keadilan pun 
yang diambil dan diterapkan dalam berhukum adalah semangat dari penegakan keadilan itu sendiri.

Selanjutnya mengenai filsafat ilmu hukum, terlebih dahulu akan diurai mengenai filsafat ilmu itu sendiri. Berbeda dengan filsafat, filsafat ilmu sulit untuk diberikan suatu batasan yang positif, karena banyak pendapat yang memiliki makna serta penekanan (emphasis) yang berbeda tentang filsafat ilmu. Tetapi, pada dasarnya filsafat ilmu adalah ilmu yang berbicara tentang ilmu pengetahuan (science of science) yang kedudukannya berada di atas ilmu lainnya (Conny R. Semiawan, dkk, 1988: 43 dan 45). Ada yang mengartikan filsafat ilmu dengan world views yang konsisten dengan dan pada beberapa pengertian didasarkan atas teori-teori ilmiah yang penting, lalu diartikan suatu eksposisi dari presuppositions dan predispositions dari para ilmuwan, dan memberi arti suatu disiplin yang di dalamnya konsep-konsep dan teori-teori tentang ilmu di analisis dan di klasifikasikan.

Pengertian ilmu hukum secara teoritis harus dibedakan dengan hukum. Ilmu hukum oleh beberapa pakar, seperti Roscoe Pound, G.W. Paton, Robert L. Hayman, Jan Gijseels, Mark van Hoecke, dan lain-lain menyebutnya dengan istilah Jurisprudence, sedangkan hukum turunan arti kata dari Law. Meskipun samasama mempunyai banyak arti dan arti yang mutlak benar tidak ada, tetapi setidaknya ada beberapa yang dapat dijadikan sebagai dasar pemahaman untuk itu. Beberapa Pendapat para ahli hukum tersebut bila dirangkum maka akan diperoleh definisi ilmu hukum lebih luas dari hukum. Karena hukum bila diartikan hanya bersifat teoritis tentang pedoman (seperangkat) aturan tingkah laku untuk mengatur ketertiban masyarakat, sedangkan ilmu hukum di samping sebagai pengetahuan yang sistematis dan terorganisir mengenai gejala hukum, struktur kekuasaan, norma-norma, hak-hak dan kewajiban

Metode studi hukum dalam arti umum, yakni mempelajar konsep hukum, gagasan, struktur, fungsi hukum, dan faktor-faktor eksternal non hukum yang mempengaruhi seperti masalah sosial, situasi politik, budaya, kondisi ekonomi, dan sistem nilai. Dengan demikian, ilmu hukum melihat kondisi intrinsik aturan hukum, dengan mempelajari gagasan-gagasan hukum yang bersifat mendasar, universal, umum, dan teoritis serta landasan pemikiran yang mendasarinya (Peter Mahmud Marzuki, 2008:11-15).

Ilmu hukum terlalu luas jangkauannya untuk didefinisikan, dikarenakan meliputi ruang gerak manusia, makhluk hidup lainnya, dan alam semesta (dari mikro kosmos sampai makro kosmos). Hukum dapat ditinjau dari segala aspek ilmu pengetahuan sesuai dengan keragaman ilmu yang dimiliki oleh manusia itu, seperti ilmu filsafat, ilmu fisika, ilmu sosiologi, ilmu politik, dan lain-lain. Hal ini merupakan bukti sederhana mengenai betapa luas dan dalamnya ilmu hukum, bahkan apabila dikaitkan dengan eksistensi manusia.

Rumusan-rumusan konsep hukum dalam ilmu hukum selalu disandingkan dengan konsep keadilan yaitu dari zaman ke zaman dan dari timur ke barat atau sebaliknya, selalu mengalami perubahan. Masa modern merupakan refleksi dari berbagai lapangan penyelidikan ilmiah, seperti Rationalisme, Empirisme, masa Aufklarung, Idealisme Jerman, Positivisme, Materialisme, Existensialisme dan Pragmatisme (Thoga H. Hutagalung, 1993:18).

Pada hakekatnya keadilan adalah kata sifat yang mempuyai arti adil atau tidak berat sebelah atau tidak pilih kasih. Sifat ini merupakan salah satu sifat manusia. Keadilan merupakan suatu konsep yang mengindikasikan adanya rasa keadilan dalam perlakuan (justice or fair treatment) (Nani Nurrachman, 2004:13).

Menurut sejarah hubungan keadilan dan hukum, dimulai di daratan Eropa, pemikiran hukum pertamatama menuju suatu aturan yang dicitakan yang telah dirancangkan dalam bentuk undang-undang, akan tetapi belum terwujud dan tidak pernah akan terwujud seutuhnya. Sesuai dengan adanya dikotomi, sehingga muncul dua istilah untuk menandakan hukum, yaitu: a. Hukum dalam arti keadilan (iustitia) atau ius/Recht (dari regere $=$ memimpin). Maka disini hukum menandakan peraturan yang adil tentang kehidupan masyarakat, sebagaimana dicita-citakan; b. Hukum dalam arti undang-undang atau lex atau wet. Kaidahkaidah yang mewajibkan itu dipandang sebagai sarana untuk mewujudkan aturan yang adil tersebut (Theo Huijbers, 1995:49).

Theo Huijbers menjelaskan perbedaan dari kedua istilah yang memang jelas dan nyata, yaitu: istilah hukum mengandung tuntutan keadilan, istilah undangundang menandakan norma-norma yang de facto digunakan untuk memenuhi tuntutan tersebut, entah tertulis atau tidak tertulis. Keadilan dalam konsep inilah sering digunakan dalam khasanah ilmu hukum. Secara falsafati, ilmu hukum memandang keadilan sebagai konsepsi falsafati yang menjadi tujuan hukum itu sendiri, dan itu tergantung dengan ideologi negara yang bersangkutan. Ada yang menjadikannya sebagai tujuan utama dalam berhukum, dan ada juga yang menomorduakannya, karena dengan alasan demi kepastian dan ketertiban hukum. 
Bicara tentang keadilan menurut Plato, keadilan dalam suatu negara dapat dipelajari dari aturan yang baik dan jiwa. Jiwa manusia terdiri dari tiga bagian, bagian pikiran (logistikon), bagian perasaan dan nafsu, baik psikis maupun jasmani (ephithumetikon), dan bagian rasa baik dan jahat (thumoeides). Jiwa itu teratur secara baik, sepanjang dihasilkan suatu kesatuan harmonis antara ketiga bagian itu. Hal ini terjadi bila perasaan dan nafsu-nafsu dikendalikan dan ditundukkan pada akal budi melalui rasa baik dan jahat. Maka keadilan (dikaiosune) terletak dalam batas yang seimbang antara ketiga bagian jiwa, sesuai dengan wujudnya masing-masing (Theo Huijbers, 1982:23).

Sedangkan menurut Aristoteles, hukum yang harus ditaati demi keadilan, dibagi menjadi hukum alam dan hukum positif. Hukum alam dianggap sebagai suatu hukum yang berlaku selalu dan dimana-mana karena hubungannya dengan aturan alam. Hukum itu tidak pernah berubah, tidak pernah lenyap dan berlaku dengan sendirinya. Lain halnya dengan hukum positif, yang sebagian besar berwujud undang-undang negara yang berlaku sesudah ditetapkan dan diresmikan isinya oleh instansi yang berwibawa. Tetapi, selain keadilan dianggap sebagai keutamaan umum (yaitu ketaatan hukum alam dan hukum positif), terdapat juga keadilan sebagai keutamaan moral khusus, yaitu yang menentukan hubungan baik antara satu orang dengan yang lainnya, lalu keadilan berada di tengah dua ekstrem (keseimbangan), dan untuk mengukur keseimbangan maka perlu ukuran kesamaan (dihitung dengan cara aritmetis atau geometris) (Theo Huijbers, 1982:29).

Keadilan yang dimaksud oleh Aristoteles beranjak dari filsafat politik, yang dikemukakan di tengahtengah berkecamuknya krisis politik di Yunani saat itu. Untuk itu, Aristoteles membagi keadilan dalam beberapa hal, yakni: a. Keadilan dalam segi-segi tertentu dalam kehidupan manusia, yaitu: 1. Keadilan menentukan bagaimana seharusnya hubungan baik di antara manusia; dan 2. Keadilan itu terletak di antara dua kutub yang ekstrim; orang harus menemukan keseimbangan dalam memperjuangkan kepentingannya sendiri; orang tidak boleh hanya memikirkan kepentingannya sendiri dan melupakan kepentingan orang lain; b. Pembagian keadilan secara garis besar, yaitu: 1. Keadilan distributif: mengatur hubungan antara masyarakat dan para anggota masyarakat, mewajibkan pemerintah untuk memberi apa yang menjadi hak para anggota; dan 2. Keadilan komutatif: mengatur hubungan antara para anggota masyarakat yang satu dan yang lain, dan mewajibkan setiap orang untuk bertindak sesuai dengan hukum alam dan atau perjanjian. Ini mengenai milik pribadi dan kepentingan pribadi; c. Keadilan yang menyangkut ketertiban umum, yaitu: 1 . Keadilan legal: mewajibkan di satu pihak lembaga legislatif untuk membuat undang-undang guna mencapai kesejahteraan umum dan mewajibkan di lain pihak para warga supaya patuh kepada undang-undang negara dan 2. Keadilan sosial mengatur hubungan antara majikan dan buruh (A. Gunawan Setiardja, 1990:21-22).

Konsep menurut Aristoteles inilah yang menurut banyak kalangan merupakan awal mula diformulasikannya keadilan, sehingga menjadi titik tolak pengembangan konsep keadilan di kemudian hari. Meskipun Plato membuat konsep keadilan tapi tidak segamblang apa yang disampaikan oleh Aristoteles. Bahkan di dunia barat masih menggunakan konsep yang dikemukakan oleh Aristoteles, karena masih dianggap relevan dijadikan dasar untuk kehidupan berbangsa dan bernegara menurut kultur barat, sehingga melahirkan konsep-konsep arti keadilan di kemudian hari, yaitu dari Era Yunani tersebut sampai dengan era yang memasuki Era Postmodern.

Dari sudut pandang hermeneutika, konsep-konsep keadilan tersebut mengikuti perkembangan zaman. Tidak melihat keadilan sebatas dari sudut pandang subjektivitas pencetus konsep, melainkan juga melihat dari sudut pandang masalah, linguistik, dan metode untuk memahaminya, sehingga pemaknaannya bisa keluar dari konsep yang terdahulu, karena ada unsur dialektika dan spekulatifnya (adanya kemungkinankemungkinan pergeseran dari hal yang terbatas dari kata yang diorientasikan pada arah makna yang dimaksud, menjadi pada hal yang tidak terbatas), mengikuti konteks ruang dan waktu.

\section{Pengertian Hukum dalam Perspektif Filsafat Hermeneutik dan Ilmu Hukum}

Disini penulis membatasi pembahasan hukum dalam perspektif filsafat hermeneutik dan filsafat ilmu hukum, sebatas konsep yang membahas kaitannya hubungan hukum dengan moral. Penulis tidak mengurai aliran dalam filsafat hukum, seperti: aliran hukum alam, positivisme hukum, utilitarianisme, mazhab sejarah, sociological jurisprudence, realisme hukum, karena efektivitasnya sudah terangkum dalam tiga tipe hukum. Penulis mengurai pendapat dari Philippe Nonet dan Philip Selznick, yang secara garis besar membagi tiga tipe hukum, yaitu: Hukum Represif, Hukum Otonom, dan Hukum Responsif (Philippe Nonet dan Philip Selznick, 2003:13). 
Menurut Howard Zein, gagasan hukum represif menganggap bahwa tatanan hukum tertentu dapat berupa ketidakadilan yang tegas. Keberadaan hukum tidak menjamin keadilan, apalagi keadilan substantif. Sebaliknya, setiap tatanan hukum memiliki potensi represif sebab hingga tingkat tertentu ia akan selalu terikat pada status quo, dan dengan memberikan baju otoritas kepada penguasa, sehingga hukum membuat kekuasaan makin efektif. Paham ini menyatakan moralitas bersifat komunal atau disebut juga dengan moralitas pembatasan (Philippe Nonet dan Philip Selznick, 2003:23).

Paham lainnya, yaitu paham positivisme secara radikal, tegas menyatakan bahwa antara hukum dan moral itu berbeda, tidak dapat disatukan. Pandangan ini beredar luas, bahkan mayoritas ilmuwan hukum dan praktisi hukum terjebak terhadap dikotomi tersebut. Kalangan ini berpendapat, bahwa hukum adalah sebuah muatan sistem walaupun kita tidak membutuhkan atau tidak seharusnya menggunakan hukum untuk menjustifikasi hukum. Guru ideologi kalangan ini adalah Hans Kelsen yang sangat mempertahankan otonomi dari hukum (hukum otonom), dan penolakannya pada hukum yang berdasarkan pada etika. Hans Kelsen pun berargumen hukum alam itu tidak ada, disana tidak ada prinsip keadilan dimana legislator dan hakim dapat merasa tertarik.

Menurutnya, validitas pada aturan khusus dalam hukum didasarkan pada aturan yang lebih kuat atau lebih luas dan lebih akhir, dari sebuah grundnorm atau sebuah norma awal atau yang kuat. Kelsen berpendapat, hukum secara khusus mungkin diperlihatkan kevalidannya jika mereka konsisten dengan norma awal. Pada awalnya berbeda secara moral, tapi lama kelamaan akan diterima (Morris Ginsberg, 2003: 203-204). Hukum ini kemudian dijadikan keyakinan hukum di negara Eropa kontinental, dan imbasnya sampai ke Indonesia.

Lebih bijak lagi aliran atau paham hukum responsif, yang pada dasarnya menyatakan keabsahan hukum didasarkan pada keadilan substantif dan aturan-aturan tunduk pada prinsip dan kebijaksanaan. Artinya, bahwa moralitas yang nampak adalah moralitas kerjasama, sementara aspirasi hukum dan politik berada dalam keadaan terpadu. Disini ketidaktaatan dinilai dalam ukuran kerugian substantif dan dipandang sebagai tumbuhnya masalah legitimasi. Kesempatan untuk berpartisipasi diperluas melalui integrasi bantuan hukum dan bantuan sosial (Mulyana W. Kusumah, 1986:13). Aliran ini, mulai membuka lebar mata hati beberapa ahli hukum untuk mengembangkan atau memodifikasinya, untuk disesuaikan keadaan bangsa dan negara masingmasing, meskipun tidak sedikit ahli hukum yang mencemoohnya.

Pengertian Hukum di zaman modern tersebut tekanannya (aksentuasi) bersifat empiris-rationalistis, sehingga mempunyai makna yang luas dan dalam, jadi dapat disebut pandangan secara holistik, diartikan bahwa hukum itu tekanannya pada kemauan manusia atau kehendak terdalam dari manusia yang diwujudkan pada suatu organisasi teratur, apakah itu penguasa atau Negara (Thoga H. Hutagalung, 1993:18).

Beranjak dari konsep-konsep tersebut, dari sudut pandang filsafat hermeneutik untuk konsep hukum represif dan hukum otonom tentu sesuatu hal yang tidak bisa dijadikan sebagai pijakan berhukum untuk era kekinian, terutama di Indonesia. Demikian halnya, karena hukum bukan merupakan monopoli dari para penguasa, melainkan hukum merupakan suatu tatanan di luar dari apa yang dinamakan peraturan tertulis.

Hukum memiliki berbagai dimensi lain, seperti budaya dan humanisme. Ada unsur transendensi disini, yakni hukum tidak boleh dipahami secara sempit (sebatas positivistik semata). Positivistik memandang hukum sebagai alat yang mengatur layaknya mesin terhadap makhluk hidup, terutama manusia. Padahal manusia sebagai makhluk hidup tentu punya dimensi budaya dan humanisme. Manusia tidak hanya dipandang sebagai kenyataan biologis naluriah sebagaimana halnya binatang, melainkan ada kenyataan psikologis, rohani, dan jasmani. Sedangkan terhadap hukum represif, filsafat hermeneutik tentu akan bisa menerima untuk pengembangan makna lebih lanjut menuju hukum yang lebih ideal untuk era saat ini di Indonesia, karena tetap membuka dan menerima dimensi atau norma lain selain apa yang ada di dalam hukum itu sendiri, sehingga unsur budaya dan humanisme masih bisa diterima konsep ini.

Pengertian lebih lanjut dari ahli filsafat sekaligus ahli hukum di Indonesia, seperti apa yang dikemukakan oleh O. Notohamidjojo, yang menyatakan secara keilmuan, pada umumnya ilmu hukum dalam teori dan praktek merupakan ilmu praktis yang menyangkut perbuatan manusia. Beliau berargumentasi, bahwa ilmu hukum menuntut pada pemangku atau pelaksananya untuk menilai dalam dua segi. Dua segi yang dimaksud adalah pertama, menilai isi peraturan hukum dan kedua menilai dalam pelaksanaan hukum. Akan tetapi kedua segi pekerjaan yuris tersebut terikat oleh norma-norma moral, keadilan, aequitas, kebenaran, dan kebaikan. Makin besar ia merasa terikat oleh norma-norma moral itu, makin baik mutunya sebagai yuris, sebagai otoritas hukum, dan semakin besar sum- 
bangannya bagi pembangunan hukum dan masyarakat dari negara (O. Notohamidjojo, 1975:39).

Selain itu, kaitannya hukum dan perlindungan hukum, menurut Sudikno Mertokusumo pada hakekatnya hukum tidak lain adalah suatu bentuk perlindungan kepentingan manusia, yang berbentuk kaidah atau norma. Oleh karena berbagai macam ancaman dan bahaya yang sering menerpa manusia, maka manusia perlu akan perlindungan terhadap kepentingan-kepentingannya agar manusia dapat hidup lebih tenteram. Perlindungan kepentingan itu tercapai dengan membentuk suatu peraturan hidup atau kaidah disertai dengan sanksi yang bersifat mengikat dan memaksa (Sudikno Mertokusumo, 1984:1).

Di era reformasi ini pun di Indonesia terbentuk suatu aliran hukum baru, yaitu hukum progresif yang menawarkan sebuah konsep baru untuk mengatasi permasalahan keadilan dan hukum di negeri ini. Progresif disini berasal dari kata progress yang berarti kemajuan. Jadi hukum hendaknya mampu mengikuti perkembangan zaman, mampu menjawab perubahan zaman dengan segala dasar didalamnya, bahkan mampu melayani masyarakat dengan menyandarkan pada aspek moralitas dari sumber daya manusia penegak hukum itu sendiri (Satjipto Rahardjo, 2007:9).

Proses pengembangan prinsip-prinsip penegakan hukum dan keadilan ini mencakup apa yang disebut sebagai tematisasi dalam apa yang dikatakan, terutama dalam dunia yang terdiri atas sistemsistem representasional yang mapan. Filsafat postmodern memandang tematisasi sebagai suatu istilah yang mengandung arti singkronisasi antara yang baik dengan yang ada dengan cara tertentu untuk menolak kekuatan waktu diakronis. Akan tetapi lebih lazim bisa juga tematisasi dijelaskan sebagai kebutuhan untuk menyuarakan tema-tema umum dalam nomos, sehingga memungkinkan adanya seruan menuju prinsip-prinsip kontekstual (Gregory Leyh, 2008:227).

Dalam pengertian seperti ini, hukum melekat dalam ontologi, dalam suatu realitas sosial bersama. Sebagai nomos, hukum juga menjadi suatu titik kritis dalam ontologi. Titik kritis ini memungkinkan para penegak hukum terlibat dalam pergulatan dalam nomos penegak hukum dalam rangka memenuhi tujuan hukum yaitu berbuat adil. Jadi tematisasi tidak hanya bersifat deskriptif, justru dimensi normatif kritis dalam hukum menuntut adanya penilaian yang rasional terhadap prinsip hukum yang bertentangan: (Gregory Leyh, 2008:227-228)
Akal pikiran memastikan bahwa istilah-istilah ini bisa tinggal berdampingan, sejalan antara yang satu dengan yang lainnya di dalam perbedaan, dalam satu tema; akal pikiran pun memastikan kesepakatan antara tema-tema yang berbeda tanpa membuyarkan masa sekarang dimana tema-tema tersebut berlangsung.

Dari uraian singkat beberapa konsep mengenai keadilan dan hukum dari sudut pandang falsafati, untuk mengimplementasikannya dikembalikan kepada masing-masing pihak (ilmuwan hukum dan praktisi hukum) untuk berkontemplasi kira-kira mana yang lebih pas untuk dijadikan model agar keluar dari kekacaubalauan sistem hukum yang ada di Indonesia saat ini. Dengan catatan, jangan sampai salah memilih konsep yang nantinya bisa membuat keadaan hukum semakin semrawut dalam realisasinya.

\section{Problematika Penegakan Hukum yang Ber- keadilan di Indonesia}

Sejak awal peradaban manusia, masalah keadilan merupakan masalah yang selalu dituntutkan. Sehingga seluruh umat manusia umumnya mendambakan keadilan hadir dalam kehidupannya. Keadilan mulai muncul bersamaan dengan munculnya konsep keadilan yang sangat banyak (sebagaimana telah diurai oleh penulis sebelumnya).

Karena masing-masing konsep memiliki plus minusnya, bahkan ada beberapa konsep yang banyak minusnya, maka dalam penerapan keadilan ini pun ditanggapi banyak pihak dengan nada skeptis, terutama dalam hal penegakan hukum, sebab beranggapan keadilan hanya milik orang tertentu saja (seperti: pemegang kekuasaan politik, sanak famili hartawan, keturunan bangsawan, dan lain-lain).

Meskipun benar apa yang dikatakan Ign. Ridwan Widyadharma, bahwa perilaku terjadi dalam dunia peradilan (the behavior of court) di Indonesia mengalami something wrong. Menurut penulis, orang pesimislah yang tidak mendapatkan suatu keadilan, karena tidak ada perjuangan memperoleh keadilan itu sendiri. Keadilan tidak semuanya di dapat dengan bersifat pasif dalam kehidupan, akan tetapi keadilan itu ada apabila kita berfikir dan berjuang untuk ke eksistensiannya, disinilah filsafat hermeneutik difungsikan (Ign. Ridwan Widyadharma, 1999:19).

Berbicara sistem peradilan, tidak lepas dengan teorinya kekuasaan kehakiman menurut John Locke dan Monstesquieu, yang menyatakan harus terpisah dengan kekuasaan lain. Pemisahan kekuasaan dimaksudkan mencegah kesewenang-wenangan dan menjamin kekuasaan kehakiman yang independen (baik secara politis, administratif, struktural, maupun personal) sesuai dengan prinsip negara hukum. 
Rasio lainnya adalah dengan adanya pemisahan kekuasaan, diharapkan akan terwujud kebebasan para penegak hukum untuk menegakkan keadilan, karena suatu persengketaan atau permasalahan harus diselesaikan dengan nilai-nilai filosofis-humanisreligius. Untuk Negara Indonesia, nilai-nilai tersebut sudah ada cerminnya yaitu Pancasila (terutama dalam Sila Pertama dan Sila Kedua).

Dari cermin itulah seharusnya para penegak hukum atau aparat di lembaga kekuasaan kehakiman bercermin ketika akan menegakkan keadilan, plus dengan menerapkan filsafat hermeneutik. Akan tetapi yang terjadi, para aparatur penegak hukum dalam menjalankan fungsi sistem peradilan justru tidak mau berkaca pada Pancasila tersebut, bahkan memalingkan diri dari nilai-nilai yang terkandung di dalam Pancasila.

Berdasarkan penelitian Indonesian Corruption Watch (ICW) pada tahun 2001 dan penelitian Jonaedi Efendi di tahun 2009 diperoleh temuan mengenai pola-pola korupsi di lembaga peradilan (judicial corruption) dari mulai penyelidikan (kepolisian), penyidikan (kejaksaan), sampai pada putusan (pengadilan). Modus judicial corruption ini dilakukan oleh segelintir orang, kelompok, bahkan berjamaah ketika melakukan perbuatan tercela yaitu memanipulasi keadilan (Wasingatu Zakiah, dkk, 2004: 9-15 dan Jonaedi Efendi, 2010:25-43).

Fakta empiris terbukti, ketidakadilan dalam masyarakat dan perbedaan penanganan suatu perkara yang mencolok antara si kaya dan si miskin atau si penguasa dan si rakyat jelata, sudah menjadi gambaran yang dianggap biasa terjadi. Tentu ditinjau dari segi asas, hal ini bertentangan dengan prinsip equality before the law, bahkan bertentangan dengan harkat dan martabat manusia itu sendiri.

Padahal kodratnya semenjak lahir masing-masing manusia merupakan pribadi yang berpotensi untuk berkembang, sehingga mempunyai hak dan kewajiban sebagai makhluk sosial dan warga negara. Untuk memenuhi hak dan kewajiban itu secara universal mengakui adanya Hak Asasi Manusia (selanjutnya disebut dengan HAM), bahkan secara tekstual oleh PBB pada tahun 1948 dituangkan di norma yang dinamakan Universal Declaration of Human Right.

HAM inilah yang kurang disensitifkan oleh para penegak hukum. Padahal penegak hukum selalu mendengungkan dalam penegakkan hukum harus berdasarkan irah-irah Demi Keadilan Berdasarkan Ketuhanan Yang Maha Esa. Bahkan dalam memaknai keadilan, ada kewajiban untuk menghormati HAM masing-masing individu atau masyarakat.
Irah-irah ini sebenarnya secara normatif tercantum dalam ketentuan Pasal 2 Undang-Undang Nomor 48 Tahun 2009 tentang Kekuasaan Kehakiman, bahkan dalam undang-undang sebelumnya (dari awal kemerdekaan sampai era reformasi pencantumannya selalu ada). Sudah menjadi kewajiban bagi para penegak hukum untuk merefleksikan irah-irah tersebut. Terutama para hakim yang dihadapannya selalu ada, bahkan dibuat dengan tangannya sendiri irah-irah tersebut dalam suatu Putusan, karena kalau tidak dipenuhi maka Putusan itu dianggap batal demi hukum. Selain diatur dalam undang-undang, irah-irah ini pun sudah sesuai dengan ketentuan dalam Pasal 29 Undang-Undang Dasar 1945 (Konstitusi Bangsa Indonesia).

Adanya kesenjangan dalam perlakukan di bidang penegakan hukum, jelas bertentangan dengan arti dari keadilan itu sendiri, seperti yang dijelaskan Aristoteles, pantas adalah suatu bentuk sama; yaitu melibatkan prinsip bahwa kasus sama seharusnya diperlakukan dalam cara yang sama dan kasus yang berbeda diperlakukan dengan cara yang berbeda. Oleh karenanya menurut Morris Ginsberg, keadilan berlawanan kata dengan: a. pelanggaran hukum, penyimpangan, ketidaktetapan, ketidakpastian, keputusan yang tidak terduga, tidak dibatasi oleh peraturan; b. sikap memihak dalam penerapan suatu peraturan, dan c. aturan yang memihak atau sewenangwenang, melibatkan diskriminasi yang tidak mendasar atau diskriminasi berdasarkan perbedaan yang tidak relevan (Morris Ginsberg, 2003:41).

Dari semua permasalahan yang ada dalam penegakkan hukum ini menurut penulis, inti yang menjadi akar terjadinya penyakit kronis hukum ini, ada pada konsep hukum yang sejak lama ada, yaitu adanya paham positivisme. Paham ini hanya mengagungkan akal pikiran, semua permasalahan hukum diselesaikan dengan logika silogisme dan mekanis (salah satu cabang dalam filsafat), sehingga yang dijadikan rujukan selalu peraturan tertulis (yang menurut Satjipto Rahardjo dalam suatu seminar menyatakan undang-undang hanya merupakan teks yang mati atau tidak bisa hidup apabila tidak ada 'ruh'nya, ruh itulah yang dinamakan keadilan di dalam masyarakat).

Singkatnya, konsep hukum yang diajarkan saat ini sudah mendarah daging ke sendi-sendi kehidupan hukum (terutama bagi para pelaku hukum) di Indonesia, adalah konsep yang lebih dari $80 \%$ bermakna positivistik, jadi dari akar inilah menjadi salah satu penyebab para penegak hukum saat ini berperilaku seperti mekanik hukum. 
Disinilah sebenarnya penegak hukum khususnya para hakim berperan untuk memaknai hukum dengan nilai-nilai moralitas dan keadilan. Dikarenakan, makna teks dalam hukum tertulis tidak sebagaimana adanya, melainkan terlepas dari keyakinan para penyusunnya dulu atau keyakinan baru para hakim.

Menurut Ronald Dworkin, seorang hakim yang mempunyai data atau informasi yang lebih banyak dibandingkan para penyusunnya bisa berkesimpulan bahwa ada klausa yang memberikan perlindungan hukum yang setara.

Bahkan hakim bisa dibenarkan bila memahami hukum mencakup misalnya larangan diskriminasi berdasarkan basis gender atau kecenderungan seksual, yakni kriteria yang tidak pernah dipikirkan oleh para penyusun teks hukum tersebut (Gregory Leyh, 2008:270).

Dengan kata lain, Dworkin mengakui bahwa pandangan interpretasi sebagai upaya untuk mencari tahu apa yang dimaksud oleh para penyusun hukum sehingga memiliki kecocokan yang sempurna dengan pandangan bahwa para penyusun hukum bisa saja keliru dalam mengaplikasikan hukum mereka secara tertulis. Alasan ini pun didapat secara fakta, bahwa para legislator (pembentuk hukum tertulis) itu bisa keliru mengenai apa yang diperbolehkan atau dilarang oleh hukum mereka sendiri, sehingga menandakan ada kesewenangan pemikiran intensionalis dalam interpretasi hukum (Gregory Leyh, 2008:271).

Dapatlah disimpulkan kondisi yang demikian, dikarenakan kurang adanya pemahaman akan makna keadilan dan hukum dari sudut pandang yang falsafati, terutama hermeneutika.

\section{Prospek Filsafat Hermeneutik dan Filsafat IImu Hukum dalam Membenahi Penegakan Hukum yang Berlandaskan Keadilan sesuai Pancasila}

Konsep keadilan di Indonesia adalah yang berasaskan keadilan sosial sebagaimana tertuang dalam Sila Ketiga dari Pancasila. Dipertegas lagi dalam Pembukaan Undang-Undang Dasar 1945 yang menyatakan "... terbentuk dalam suatu susunan negara Republik Indonesia yang berkedaulatan rakyat, dengan berdasarkan kepada Ketuhanan Yang Maha Esa, Kemanusiaan yang adil dan beradab, Persatuan Indonesia dan Kerakyatan yang dipimpin oleh hikmat kebijaksanaan dalam permusyawaratan/perwakilan, serta dengan mewujudkan suatu keadilan sosial bagi seluruh rakyat Indonesia". Selanjutnya, dikatakan bahwa Pemerintah Indonesia "ikut melaksanakan ketertiban dunia yang berdasarkan kemerdekaan, perdamaian abadi dan keadilan sosial".
Konsep tersebut dari sudut pandang hermeneutik menyiratkan bahwa adanya kesadaran penuh, agar keadilan sosial harus dilaksanakan dalam masyarakat sepenuhnya. Akan tetapi dalam kenyataannya hakekat keadilan sosial kurang dipahami arti serta isinya, sehingga cita-cita masyarakat yang adil dan makmur itu masih jauh dari harapan semua orang di Indonesia, khususnya para pencari keadilan.

Dengan demikian, hermeneutika memandang bahwa pemahaman terhadap keadilan sosial selalu diinterpretasikan dengan sebuah isyarat bahwa pemahaman itu dikondisikan dengan konteks dimana pemahaman terhadap penerapan keadilan sosial itu terjadi. Pemahaman tersebut merupakan aplikasi dalam pengertian bahwa keadilan sosial tidak hanya muncul dari latar belakang kontekstual namun juga memperhatikan ciri-ciri spesifik dari konteks tersebut, dengan memfokuskan diri pada beberapa bagian dan mengkonfigurasikan kembali konteksnya melalui upaya pencapaian terhadap pemahaman keadilan sosial sebagaimana dimaksud dalam Pancasila.

Mohammad Hatta senantiasa mengemukakan Pancasila terdiri dari dua lapis fundamen, yaitu: a. fundamen politik; b. fundamen moral (etik agama). Negara dan pemerintahannya akan memperoleh dasar yang kokoh dan memerintahkan berbuat benar apabila meletakkan dasar moral di atas. Dengan politik pemerintahan yang berpegang kepada moral yang tinggi diciptakan tercapainya suatu keadilan sosial bagi seluruh rakyat Indonesia (Roeslan Saleh, 1991: 46). Selanjutnya dikatakan bahwa: Dasar Ketuhanan Yang Maha Esa menjadi dasar yang memimpin citacita negara kita, yang memberikan jiwa kepada usaha menyelenggarakan segala yang benar, adil dan baik. Sedangkan dasar kemanusiaan yang adil dan beradab adalah kelanjutan dalam perbuatan dan praktek hidup daripada dasar yang memimpin tadi. Dasar kemanusiaan yang adil dan beradab harus menyusul, berangkaian dengan dasar yang pertama. Letaknya tidak dapat dipisah dari itu, sebab dia harus dipandang sebagai kelanjutan ke dalam praktek hidup daripada cita-cita dan amal Ketuhanan Yang Maha Esa.

Kaitannya Pancasila dengan penegakan hukum yang berkeadilan, penulis sependapat dengan Sudjito yang menyatakan bahwa sebenarnya konsep negara hukum Indonesia merupakan perpaduan 3 (tiga) unsur yaitu Pancasila, hukum nasional dan tujuan negara. Ketiga unsur tersebut merupakan satu kesatuan utuh. Pancasila merupakan dasar pembentukan hukum nasional. Hukum nasional disusun sebagai sarana untuk mencapai tujuan negara. Tidak ada artinya hukum nasional disusun apabila tidak mampu 
mengantarkan bangsa Indonesia mencapai kehidupan yang sejahtera dan bahagia dalam naungan ridha Illahi (Sudjito, 2009:5). Dengan demikian secara falsafati hermeneutika dan ilmu hukum, konsep penegakan hukum yang berdasarkan "Keadilan" dan "Ketuhanan Yang Maha Esa" pun wajib hukumnya mengacu pada nilai-nilai yang terkandung dalam Pancasila.

Pancasila selain sebagai komponen pokok sistem nilai hukum nasional dan staatsfundamentalnorms, termasuk dalam lingkup kefilsafatan bangsa dan negara Indonesia. Kedudukan Pancasila sebagai filsafat dapat ditinjau paling tidak menurut Abubakar Busro dengan tiga kenyataan, yakni kenyataan materiil (dari jangkauan dan isinya bersifat nilainilai fundamental, universal, komprehensif, dan metafisis, bahkan pokok-pokok pengajarannya meliputi nilai-nilai keagamaan dan kemanusiaan), kenyataan fungsional praktis (merupakan jalinan tata nilai dalam sosio-budaya bangsa Indonesia, sehingga wujudnya dapat dilihat berupa adanya prinsip kepercayaan kepada Tuhan, tepa selira, setia kawan, kekeluargaan, gotong-royong, musyawarahmufakat, dan lain-lain), dan kenyataan formal (para Pendiri Negara mengangkat dan merumuskan Pancasila sebagai ideologi yang wujudnya tampak dalam Pembukaan UUD 1945 sebagai dasar Negara Kesatuan Republik Indonesia) (Abubakar Busro, 1989:26-27).

Istilah adil dan beradab di dalam sila kedua Pancasila, oleh Notonagoro dimaknai dengan rasa kemanusiaan yang adil terhadap diri sendiri, terhadap sesama manusia, terhadap Tuhan atau causa prima. Disini terkandung prinsip perikemanusiaan atau internasionalisme dan terlaksananya penjelmaan dari pada unsur-unsur hakekat manusia, jiwaraga, akalrasa-kehendak serta sifat kodrat perseorangan dan makhluk sosial. Semua ini dikarenakan kedudukan kodrat pribadi berdiri sendiri dan makhluk Tuhan Yang Maha Esa sebagai causa prima dalam kesatuan majemuk-tunggal (monopluralis), itu adalah dalam bentuk dan penyelenggaraan hidup yang bermartabat setinggi-tingginya (Notonagoro, 1987:99-100).

Mengenai hubungan hukum dengan sosial kemasyarakatan, ada ungkapan yang menyatakan di samping masalah tertinggalnya hukum oleh perubahan-perubahan sosial, maka mungkin akan muncul problem lain yaitu tertinggalnya perkembangan masyarakat oleh perubahan yang terjadi dalam hukum atau perubahan yang ingin dicapai melalui hukum tidak diikuti oleh masyarakat. Menurut penulis, hal ini kurang pas karena hukum harus seiring sejalan dengan masyarakat, dan senantiasa bergandengan dengan apa yang namanya keadilan. Jadi tidak ada yang saling mendahului, ibarat kepingan mata uang hukum tidak bisa lepas dari masyarakat, meskipun dua hal yang berbeda, yang menjadi pengikat (di tengah-tengah) kepingan tersebut adalah keadilan.

Dalam kaitannya hubungan keadilan, hukum dan masyarakat, penulis sepakat dengan pendapat Satjipto Rahardjo, bahwa ilmu hukum harus mengawal hukum terus-menerus yang mengalami perkembangan dan perubahan sampai dengan hari ini, Sehingga akan dipahami ternyata hukum itu tidak otonom. Hukum itulah merupakan bagian dari pranata untuk hidup secara tertib. Jadi, hukum adalah untuk manusia. Dengan demikian hukum tunduk pada kehidupan sosial manusia yang jauh lebih luas (Satjipto Rahardjo, 2009:74). Menurut penulis maka perlu adanya suatu elaborasi mengenai hukum progresif yang digagas oleh Satjipto Rahardjo untuk menyelesaikan masalah koheren hubungan keadilan, hukum, dan masyarakat. Dalam hukum progresif selalu disemaikan bagi pengembangan kekuatan yang tersimpan di dalam hukum, sehingga menolak cara berhukum yang menyebabkan dinamika hukum hilang karena hukum menjadi statis dan stagnan.

Terhambatnya kekuatan yang sebenarnya, ada secara inheren dalam hukum, sebagai akibat dari ulah para penegak hukum sendiri yang menyebabkannya, yaitu dengan menerapkan cara-cara berhukum yang hanya dengan mengeja teks undang-undang. Padahal hukum tidak berdiri sendiri, adakalanya memasuki wilayah keilmuan yang lain. Misalnya memasuki wilayah psikologi, dengan itu dapat diperoleh suatu konsep bahwa hukum tidak hanya berurusan dengan peraturan melainkan juga perilaku manusia. Ada tiga solusi yang coba ditawarkan oleh Satjipto Rahardjo melalui gagasan atau ide hukum progresifnya, kaitannya dengan keterpurukan hukum di Indonesia, yaitu: Pertama, penggunaan kecerdasan spiritual untuk bangun dari keterpurukan hukum, memberi pesan penting kepada kita (terutama akademisi dan praktisi hukum) untuk berani mencari jalan baru (rule breaking) dan tidak membiarkan diri terkekang cara menjalankan hukum yang lama dan tradisional yang jelas-jelas lebih banyak melukai rasa keadilan. Kedua, pencarian makna lebih dalam hendaknya menjadi ukuran baru dalam menjalankan hukum dan bernegara hukum. Para stakeholder hukum di Indonesia (akademisi dan praktisi hukum) didorong untuk selalu bertanya kepada nurani tentang makna hukum lebih dalam. Ketiga, hukum hendaknya dijalankan tidak menurut prinsip logika saja, tetapi dengan perasaan, kepedulian, dan semangat keterlibatan (compassion) 
kepada bangsa kita yang sedang menderita. Segala daya dan upaya hendaknya dilakukan untuk bangun dari keterpurukan dan sekali lagi perlu menggugat diri yang selama ini mempunyai cara berpikir yang lebih banyak mendatangkan kesusahan. Sudah semestinya hukum merupakan institusi yang berfungsi untuk menjadikan bangsa kita, merasa sejahtera dan bahagia (Satjipto Rahardjo, 2007:21-22).

Dari tiga solusi yang ditawarkan oleh Satjipto Rahardjo tersebut, penulis menilai keadilan yang dicapai hanya sebagai keadilan dari sudut pandang spiritual justice, moral justice dan social justice, tetapi belum secara tegas menyentuh pada philosophy and legal justice yang sekiranya dapat menjembatani penganut paham hukum doktrinal dan nondoktrinal, sehingga penulis menambahkan satu solusi lagi agar terwujud keadilan secara hermeneutik dan legal filosofis, yaitu penerapan hukum secara filosofis tetap berpedoman kepada Pancasila dan Pembukaan Undang-Undang Dasar 1945 yang berisi mengenai visi dan misi bangsa dan negara Indonesia, karena keadilan yang dicita-citakan dalam Pancasila dan Pembukaan Undang-Undang Dasar 1945 di samping bersifat relijius-sosialis, juga bersifat luhur, universal, dan jauh dari sifat sekuler-individualistis-materialistis. Keduanya ini pun bisa sebagai perekat bangsa dan negara Indonesia, yang saat ini sedang bercerai-berai terutama kalangan atau penganut dua paham tersebut (doktrinal dan non doktrinal). Karena Pancasila oleh kalangan ahli hukum doktrinal di Indonesia diakui sebagai staatsfundamentalnorms, begitu pun dan Pembukaan UUD 1945 dianggap sebagai sesuatu yang sakral keberadaannya, sehingga harus mereka ikuti. Sedangkan dari pemikiran-pemikiran ahli hukum nondoktrinal di Indonesia, Pancasila maupun dan Pembukaan UUD 1945 sudah sesuai dengan alur pikirnya atau konsep yang selama ini dibangun.

\section{PENUTUP}

\section{Kesimpulan}

Faktor-faktor yang menyebabkan keadilan sulit untuk ditegakkan di negara Indonesia ditinjau dari filsafat hermeneutik dan filsafat ilmu hukum adalah faktor yang bersifat fundamental, yakni: salahnya sistem pendidikan hukum yang melulu mengajarkan pola pikir yuridis-normatif (bahkan prosentase pengajarannya lebih dari $80 \%$ berkisar sistem dan filsafat hukum yang positivistik). Faktor lainnya adalah kurangnya pendidikan karakter bangsa Indonesia dan masih lemahnya pelaksanaan moral dalam penegakan hukum. Dan yang terakhir kurang didukungnya konsep hukum nondoktrinal oleh banyak akademisi (ilmuwan) dan praktisi hukum di Indonesia, karena pandangan positivistiknya sudah mendarah daging bersemayam dalam pikirannya.

Sedangkan, solusi terbaik untuk menjawab permasalahan tersebut bagi para penegak hukum di Indonesia adalah mengembalikan permasalahan kepada nilai jati diri bangsa sesungguhnya yakni Pancasila dan Pembukaan UUD 1945, serta menerima konsep hukum baru yaitu hukum progresif (bagian dari hukum nondoktrinal) yang lebih menekankan pada nilai-nilai moral-sosial-relijius dan memandang suatu permasalahan ditinjau dari berbagai disiplin keilmuan yang bisa sinkron terhadap ilmu hukum itu sendiri.

\section{Rekomendasi}

Perlu adanya reformasi kurikulum pengajaran bidang hukum di perguruan tinggi (S1, S2, dan S3). Ketika sedang mengajar, sebaiknya tiap-tiap mata kuliah selalu disisipi nilai-nilai moral dan humanisme sesuai karakter dan budaya bangsa Indonesia secara komprehensif. Bahkan untuk seluruh mata kuliah lebih diutamakan pada "penyemaian" landasan teori-teori atau filsafat hukumnya melalui metode hermeneutik yang pro keadilan dan terbuka dengan ilmu-ilmu lainnya. Terlebih penting ada peran pemerintah pusat untuk mendukung berkembangnya hukum nondoktrinal, karena konfigurasi politik hukum nondoktrinal sangat besar pengaruhnya apabila ada political will dari pemerintah pusat.

\section{DAFTAR PUSTAKA \\ Buku:}

Bakry, H. Hasbullah, 1981, Sistematik Filsafat, Jakarta: Widjaya Jayakarta.

Busro, Abubakar, 1989, Nilai dan Berbagai Aspeknya dalam Hukum, Jakarta: Bhrata.

Capra, Fritjof, 1982, The Turning Point: Science, Society, and the Rising Culture, London: Flamingo an Imprint of Harper Collins Publishers.

Efendi, Jonaedi, 2010, Mafia Hukum: Menguak Praktik Tersembunyi Jual-Beli Hukum dan Alternative Pemberantasannya dalam Perspektif Hukum Progresif, Jakarta: Prestasi Pustaka Publisher.

Ginsberg, Morris, 2003, Keadilan dalam Masyarakat, terjemahan dari "On Justice in Society", Yogyakarta: Pondok Edukasi.

Huijbers, Theo, 1995, Filsafat Hukum, Yogyakarta: Kanisius.

, Filsafat Hukum dalam Lintasan Sejarah, Yogyakarta: Kanisius. 
Hutagalung, Thoga H., 1993, Beberapa Pemikiran tentang Hukum yang Dikemukakan oleh Beberapa Aliran, Bandung: CV. Armico.

Kusumah, Mulyana W., 1986, Perspektif, Teori, dan Kebijaksanaan Hukum, Jakarta: CV. Rajawali.

Leyh, Gregory, 2008, Hermeneutika Hukum: Sejarah, Teori, dan Praktik (terjemahan oleh M. Khazim), Bandung: Nusa Media.

Marzuki, Peter Mahmud, 2008, Pengantar Ilmu Hukum, Jakarta: Kencana.

Mertokusumo, Sudikno, 1984, Bunga Rampai Ilmu Hukum, Yogyakarta: Liberty.

Nurrachman, Nani, 2004, dari tulisannya yang berjudul Keadilan dalam Perspektif Psiko-Sosial dalam buku Keadilan Sosial: Upaya Mencari Makna Kesejahteraan Bersama di Indonesia, Jakarta: Kompas.

Notonagoro, 1987, Pancasila Secara Ilmiah Populer, Jakarta: Bina Aksara.

Notohamidjojo O., 1975, Demi Keadilan dan Kemanusiaan: Beberapa Bab dari Filsafat Hukum, Jakarta: BPK Gunung Mulia.

Nonet, Philippe dan Selznick, Philip, 2003, Hukum Responsif: Pilihan di Masa Transisi (terjemahan dari "Law \& Society in Transition: Toward Responsive Law" dengan penerjemah: Rafael Edy Bosco, Jakarta: HuMa.

Rahardjo, Satjipto, 2007, Membedah Hukum Progresif, Jakarta: Kompas. , 2009, Lapisan-Lapisan dalam Studi Hukum, Malang: Bayu Media Publishing.
, 2009, Pendidikan Hukum sebagai Pendidikan Manusia: Kaitannya dengan Profesi Hukum dan Pembangunan Hukum Nasional, Yogyakarta: Genta Publishing.

Saleh, Roeslan, 1991, Penjabaran Pancasila dan Undang-Undang Dasar 1945 dalam Perundangundangan, Jakarta: Sinar Grafika.

Semiawan, Conny R., dkk, 1988, Dimensi Kreatif dalam Filsafat llmu, Bandung: Remadja Karya.

Setiardja, A. Gunawan, 1990, Dialektika Hukum dan Moral: dalam Pembangunan Masyarakat Indonesia, Yogyakarta: Kanisius.

Sudjito (ahli filsafat ilmu hukum dari UGM Yogyakarta), 2006, Chaos Theory of Law: Penjelasan atas Keteraturan dan Ketidakteraturan, dalam Media Hukum Volume 18, Nomor 2. , 2009, Negara Hukum dalam Perspektif Pancasila, Yogyakarta, Makalah yang disampaikan dalam Kongres Pancasila, Kerjasama Mahkamah Konstitusi RI dan Universitas Gadjah Mada.

Sugiharto, Bambang I., 1996, Postmodernisme: Tantangan bagi Filsafat, Yogyakarta: Kanisius.

Widyadharma, Ign. Ridwan, 1999, Menata Peradilan Indonesia, Semarang: Badan Penerbit Universitas Diponegoro.

Zakiah, Wasingatu, dkk, 2004, Panduan Eksaminasi Publik dan Hasil Eksaminasi Publik Perkara Akbar Tanjung, Jakarta: Indonesian Corruption Watch. 